\title{
PENGARUH BEBAN KERJA DAN KEJENUHAN KERJA (BURNOUT) TERHADAP MOTIVASI KERJA GURU DI YAYASAN PENDIDIKAN CENDANA
}

\author{
Bambang Rudyanto ${ }^{1)}$ \\ Hasnah Faizah $\mathbf{A} \mathbf{R}^{2)}$ \\ Zulkarnain ${ }^{3)}$ \\ 1) SMA Cendana Pekanbaru \\ 2) Lecturer of Education Management Study Programme PPs University of Riau \\ ${ }^{3)}$ Lecturer of Education Management Study Programme PPs University of Riau \\ Email: bangrudyaja@gmail.com
}

\begin{abstract}
The purpose of this study is to analyze the effect of independent variables on the dependent variable, namely the effect of workload and work saturation (burnout) on teacher work motivation at the Cendana Education Foundation. This study uses survey methodolgy by using a questionnaire as a data collection instrument. A quantitative research with a population of 59 people. The sampling was done by proportional random sampling, in order to obtain the sample of 52 people. The data analysis technique was carried out in two stages: descriptive and inferential. Then, the data obtained were analyzed by regression analysis, regression coefficient and coefficient of determination. The results shows that there is a positive influence between workload and teacher work motivation by $30.4 \%$. Subsequently, there is a negative influence between job boredom on teacher work motivation by $22.2 \%$, and there is a joint influence between workload and work saturation variables on work motivation by $45.7 \%$. Thus, the influence of workload and work saturation variables on work motivation is in a moderate interpretation.
\end{abstract}

Keywords: Workload; Work Saturation; Teacher Work Motivation 


\begin{abstract}
ABSTRAK
Tujuan dalam penelitian ini adalah untuk menganalisis pengaruh variabel bebas terhadap variabel terikat yaitu Pengaruh Beban Kerja dan Kejenuhan Kerja (Burnout) Terhadap Motivasi Kerja Guru di Yayasan Pendidikan Cendana. Penelitian ini menggunakan metode survey dengan menggunakan angket sebagai alat pengumpul data. Jenis penelitian kuantitatif dengan populasi sebanyak 59 orang. Pengambilan sampel dilakukkan dengan cara proporsional random sampling, sehingga diperoleh sampel sebanyak 52 orang. Teknik analisa data yang dilakukan dalam dua tahap yakni secara deskriptif dan inferensial. Kemudian data yang diperoleh dianalisis dengan analisis regresi, koefisien regresi dan koefisien determinasi. Hasil penelitian menunjukkan terdapat pengaruh yang positif antara beban kerja terhadap motivasi kerja guru sebesar $30,4 \%$. Terdapat pengaruh yang negatif antara kejenuhan kerja terhadap motivasi kerja guru sebesar $22,2 \%$, serta terdapat pengaruh secara bersama-sama antara variabel beban kerja dan kejenuhan kerja terhadap motivasi kerja sebesar 45,7\%. Dengan demikian, pengaruh variabel beban kerja dan kejenuhan kerja terhadap motivasi kerja tersebut berada pada tafsiran sedang.
\end{abstract}

Kata Kunci: Beban Kerja; Kejenuhan Kerja (Burnout); Motivasi Kerja Guru

\section{PENDAHULUAN}

Motivasi merupakan suatu hal yang harus selalu diperhatikan, baik itu bekerja secara mandiri apa lagi bekerja dengan ruang lingkup yang lebih besar seperti perusahaan atau lembaga pendidikan. Dengan motivasi yang tinggi, seseorang dapat bekerja secara maksimal. Pentingnya menjaga motivasi kerja pada diri seseorang juga akan memberikan dampak yang signifikan terhadap tujuan dari perusahaan tersebut. Motivasi kerja guru adalah sebuah rangsangan yang terdapat pada seorang guru baik dari dalam atau dari luar, yang dapat menumbuhkan semangat kerja bagi guru guna mencapai target yang diberikan. Sebuah motivasi erat kaitannya atau berbanding lurus dengan cita-cita seseorang. Semakin tinggi cita-cita seseorang semakin tinggi pula motivasi dalam dirinya untuk berbuat. Guru yang memiliki motivasi yang tinggi tentu memiliki pola pikir yang berbeda dengan guru yang tanpa motivasi atau motivasi rendah.
Motivasi kerja merupakan sebuah kemauan atau keinginan seseorang yang berasal dari dalam ataupun luar untuk melakukan suatu kegiatan. Hal ini senada dengan Uno (2017) yang menyatakan bahwa motivasi kerja merupakan sebuah stimulus yang terdapat dalam diri seseorang maupun dari luar diri seseorang untuk melakukan suatu perkerjaan. Hal ini sesuai dengan Hasibuan (2016) yang menyatakan bahwa motivasi kerja merupakan pemberian rangsangan yang mampu mempengaruhi seseorang untuk bergairah dalam bekerja, bekerja sama di dalam tim, efektif dan terintegrasi dengan segala hasil usahanya guna mencapai kepuasan.

Menurut Suharti Ningsih, (2017) ada beberapa penyebab yang dapat mempengaruhi motivasi kerja yaitu: 1) beban kerja, 2) kejenuhan kerja, 3) serta konflik kerja. Dari penjelasan tersebut dapat dapat disimpulkan bahwa beban kerja dan kejenuhan kerja merupakan salah satu pemicu yang dapat mempengaruhi motivasi kerja. 
Beban kerja adalah sejumlah kegiatan yang harus diselesaikan dalam jangka waktu tertentu. Beban kerja guru diatur dalam Permendiknas (2009) no. 39 pasal 1 menjelaskan bahwa beban kerja yang harus diemban seorang guru minimal 24 dengan batas maksimal 40 jam tatap muka dalam sepekan. Beban kerja yang diemban guru tersebut jika ditambah dengan tugas seorang guru seperti yang tertuang dalam UU no. 14 tahun 2005 pasal 1 , tentu bukan merupakan tugas yang mudah. Selain mengajar guru juga harus mampu mendidik dan membentuk akhlak siswa kearah yang lebih baik. Hal ini senada dengan Riadi (2018) yang menyatakan bahwa beban kerja adalah sekumpulan proses atau kewajiban dalam suatu organisasi yang harus diselesaikan pada periode tertentu. Senada dengan Riadi, Schultz dan Schultz (dalam Hasby, 2017) menyatakan beban kerja adalah terlalu banyak kegiatan atau kewajiban yang terlalu berat bagi pegawai yang diselesaikan pada waktu tertentu.

Selain beban kerja, kejenuhan kerja juga harus diperhatikan untuk menjaga motivasi kerja. Kejenuhan kerja atau burnout adalah suatu kondisi fisik, atau mental yang sangat drop yang diakibatkan oleh situasi kerja yang sangat banyak menuntut. Hal ini sesuai dengan Pines (dalam Yusuf, 2011) yang menyatakan bahwa kejenuhan kerja merupakan gejala emosi yang menimpa seseorang berupa rasa lelah yang diakibatkan tuntutan pekerjaan yang dirasakan berlebihan. Senada dengan hal tersebut Mondy (dalam Santoso, Hidayanti 2016) mendefinisikan kejenuhan kerja (burnout) merupakan situasi yang tidak nyaman yang diakibatkan hilangnya tujuan seseorang untuk apa bekerja dan semangat untuk menyelesaikan target pekerjaan.

Menurut Maslach and Leiter, (2016), menyatakan bahwa kejenuhan kerja dipengaruhi oleh faktor-faktor sebagai berikut, yaitu: 1) beban kerja yang tinggi. Hal ini disebabkan oleh karyawan melakukan sebuah pekerjaan yang melebihi kapasitasnya, 2) kontrol yang lemah di dalam pekerjaan, 3) kurangnya pemberian apresiasi atau penghargaan. Apresiasi bukan sekedar uang atau insentif namun dapat berupa pujian atau hal-hal positif lainnya yang mampu meningkatkan produktifitas dalam bekerja, 4) terpecah atau tersisih didalam lingkungan kerja, 5) tidak diperlakukan dengan adil, dan 6) Mengerjakan sesuatu yang bertentangan dengan nilai atau norma.

Hasil observasi yang dilakukan peneliti di SMA Cendana Pekanbaru dan SMP Cendana Pekanbaru menunjukan bahwa motivasi kerja sebagian guru mengalami penurunan seperti masuk kelas setelah bel berbunyi, pelaksanaan pembelajaran guru di kelas belum optimal, serta dalam mengajar di kelas masih terdapat guru yang kurang fokus meskipun tidak mengabaikan dari esensi pembelajaran yang dilakukan. Berdasarkan uraian latar belakang tersebut, maka penulis tertarik untuk melakukan penelitian tentang motivasi kerja guru yang kaitannya dengan beban kerja guru dan kejenuhan kerja guru dengan judul" Pengaruh Beban Kerja dan Kejenuhan Kerja (Burnout) terhadap Motivasi Kerja Guru di Yayasan Pendidikan Cendana".

Berdasarkan pada latar belakang maka dapat dirumuskan beberapa masalah pada penelitian ini sebagai berikut: 1) Bagaimanakah motivasi kerja guru di Yayasan Pendidikan Cendana dilihat dari sisi demografi? 2)Bagaimanakah beban kerja guru di Yayasan Pendidikan Cendana dilihat dari sisi demografi? 3) Bagaimanakah tingkat kejenuhan kerja guru di Yayasan Pendidikan Cendana dilihat dari sisi demografi? 4)Apakah terdapat pengaruh yang signifikan antara beban kerja terhadap motivasi kerja guru di Yayasan Pendidikan Cendana? 5)Apakah terdapat pengaruh yang 
signifikan antara kejenuhan kerja terhadap motivasi kerja guru di Yayasan Pendidikan Cendana? 6) Apakah terdapat pengaruh yang signifikan antara beban kerja dan kejenuhan kerja terhadap motivasi kerja guru di Yayasan Pendidikan Cendana?

Tujuan penelitian ini adalah sebagai berikut: 1) Mendeskripsikan motivasi kerja guru di Yayasan Pendidikan Cendana dari sisi demografi. 2) Mendeskripsikan beban kerja guru di Yayasan Pendidikan Cendana dari sisi demografi. 3) Mendeskripsikan tingkat kejenuhan kerja guru di Yayasan Pendidikan Cendana dari sisi demografi. 4) Menganalisis pengaruh yang signifikan beban kerja terhadap motivasi kerja guru di Yayasan Pendidikan Cendana. 5) Menganalisis pengaruh yang signifikan kejenuhan kerja terhadap motivasi kerja guru di Yayasan Pendidikan Cendana. 6) Menganalisis pengaruh yang signifikan beban kerja dan kejenuhan kerja terhadap motivasi kerja guru di Yayasan Pendidikan Cendana.

\section{KAJIAN TEORITIS}

\section{Motivasi Kerja Guru}

Motivasi diambil dari bahasa latin yaitu "movere" yang berarti dorongan yang terdapat dalam diri seseorang untuk melakukan suatu tindakan atau perbuatan. Motivasi kerja adalah sesuatu yang bisa menumbuhkan semangat di dalam bekerja. Hal ini senada dengan Fitria, Hasnah Faizah, and Azhar, (2017) dalam penelitiannya yang menyatakan bahwa terdapat hubungan yang kuat antara motivasi dengan kinerja seseorang. Motivasi kerja adalah sebagai motor utama kesuksesan dalam sebuah pekerjaan. Semakin besar keinginan untuk sukses dalam diri seseorang maka peluang sukses itu makin dekat untuk diraih. Oleh karena itu seorang pimpinan perlu memberikan motivasi kepada bawahan agar target-target yang telah disusun bisa tercapai.

Seseorang yang memiliki motivasi kerja yang tinggi biasanya akan memperoleh hasil atau prestasi yang tinggi, begitu juga sebaliknya. Hal ini juga diperkuat oleh Kurniadin dan Machali (2016) yang menyatakan bahwa motivasi adalah sebuah kekuatan yang senantiasa dipengaruhi oleh faktor lain seperti taraf intelegensi, kemampuan fisik seseorang, pengalaman yang terjadi di masa lalu, lingkungan kerja dan cita-cita atau keinginan hidup. Berdasarkan definisi yang dibuat oleh para ahli tersebut maka dapat disintesiskan bahwa motivasi kerja guru adalah suatu cara yang dilakukan untuk menggerakkan seorang guru, agar berperilaku kearah yang diharapkan guna mencapai tujuan tertentu. Dengan cara yang tepat maka tujuan atau visi misi dari suatu lembaga pendidikan dapat di capai dengan baik.

Menurut Sutermeister (dalam Mulyadi, 2010) yang menyatakan bahwa faktor-faktor yang mempengaruhi motivasi kerja, yaitu: 1) kondisi fisik lingkungan kerja (Physical Working Condition). Masalah yang berkaitan dengan kondisi fisik lingkungan kerja antara lain masalah kebisingan (noise), pencahayaan (lighting), ventilasi (ventilation), suhu (temperature), keamanan (safety), waktu istirahat (rest periods), kelembaban dan musik (music), 2) kondisi sosial lingkungan kerja (Social Working Conditions). Kondisi sosial lingkungan kerja meliputi empat faktor utama, yaitu: organisasi formal, organisasi informal, pemimpin (leader of supervisors) dan serikat pekerja (union), dan 3) keterpenuhan kebutuhan dasar individu (Fulfilment of Individual Basic Needs).

\section{Beban Kerja}

Beban kerja dapat juga dikatakan dengan sejauh mana kemampuan suatu 
individu tersebut dapat menyelesaikan tugas yang diembannya dalam waktu tertentu. Hal ini senada dengan Riadi (2018) yang menyatakan bahwa beban kerja adalah sekumpulan proses atau kewajiban dalam suatu organisasi yang harus diselesaikan pada periode tertentu. Senada dengan Riadi, Schultz dan Schultz (dalam Hasby, 2017) menyatakan beban kerja adalah terlalu banyak kegiatan atau kewajiban yang terlalu berat bagi pegawai yang diselesaikan pada waktu tertentu.

Beban kerja juga bisa didefinisikan sebagai sekumpulan pekerjaan dalam periode setahun di kali waktu kerja normal. Hal ini senada dengan Utomo (dalam Amalia, 2017) yang menyatakan beban kerja adalah sekumpulan pekerjaan dalam setahun yang dipikul suatu uni lembaga merupakan hasil kali antara banyaknya perkerjaan dengan waktu kerja yang wajar.

Menurut Tarwaka (dalam Rizal, 2018) menyatakan bahwa yang termasuk kedalam ukuran dimensi beban kerja berkaitan dengan performasi, yaitu: 1) beban waktu atau (time load); beban waktu yang menggambarkan jumlah waktu yang tersedia untuk melaksanakan perencanaan, pelaksanaan pengawasan kerja, 2) beban usaha mental (mental effort load) yaitu usaha mental yang dibutuhkan dalam menyelesaikan suatu pekerjaan, dan 3) beban tekanan psikologis (psychological stress load) yang menggambarkan tingkat resiko pekerjaan, kebingungan, dan stres kerja.

Gibson (dalam Chandra, 2017), menyatakan bahwa beban kerja dipengaruhi oleh faktor-faktor, yaitu: 1) tekanan waktu, 2) jadwal kerja atau jam kerja, 3) peran yang tidak jelas atau konflik peran, 4) kebisingan, 5) informasi yang berlebih, 6) suasana kerja yang panas, 7) pekerjaan yang berulang-ulang, dan 8) tanggung jawab.

\section{Kejenuhan Kerja (Burnout)}

Kejenuhan kerja adalah suatu kondisi atau keadaan yang menimpa seseorang dikarenakan berbagai faktor sehingga mengakibatkan produktivitasnya menurun. Salah satu faktor tersebut adalah desakan atau tuntutan dari pekerjaan. Hal ini sesuai dengan Schaufeli \& Buunk (dalam Dedi Santoso, Hidayanti, 2016) yang menyatakan bahwa kejenuhan kerja merupakan berlebihnya desakan atau tuntutan terhadap suatu pekerjaan. Senada dengan hal tersebut Mondy (dalam Dedi Santoso, Hidayanti, 2016) mendefinisikan kejenuhan kerja (burnout) merupakan situasi yang tidak nyaman yang diakibatkan hilangnya tujuan seseorang untuk apa bekerja dan semangat untuk menyelesaikan target pekerjaan.

Hal ini diperkuat oleh Maslach (dalam Qureshi, 2013) yang menyatakan bahwa kejenuhan kerja merupakan bangunan multidimensi yang disebabkan dari kelelahan emosional, depersonalisasi, serta penurunan prestasi pribadi yang dapat terjadi di antara individu yang bekerja secara luas dengan orang lain di bawah tekanan waktu yang cukup lama. Dapat disinitesiskan, bahwa kejenuhan kerja merupakan suatu kondisi yang tidak nyaman yang dialami seseorang akibat berlebihnya desakan atau tuntutan terhadap suatu pekerjaan, yang mengakibatkan kelelahan emosional, depersonalisasi, serta penurunan prestasi pribadi.

\section{METODOLOGI PENELITIAN}

Jenis penelitian yang dilakukan adalah penelitian survei dengan pendekatan penelitian kuantitatif. Penelitian survei bertujuan untuk menganalisis pengaruh variabel bebas terhadap variabel terikat. Adapun alasan memilih penelitian survei ini adalah untuk melihat seberapa besar pengaruh variabel bebas terhadap variabel terikat. Variabel bebas dalam penelitian ini adalah beban kerja (X1) dan kejenuhan kerja (X2) 
sedangkan variabel terikat adalah motivasi kerja (Y). Penelitian ini dilakukan di wilayah Rumbai dengan objek penelitian Sekolah di bawah naungan Yayasan Pendidikan Cendana distrik Rumbai. Populasi dari penelitian ini adalah guruguru di lingkungan Yayasan Pendidikan Cendana Rumbai yang berjumlah sebanyak 59 orang. Sedangkan ukuran sampel dihitung dengan menggunakan rumus Slovin sehingga diperoleh sebanyak 52 orang, dengan teknik proportional random sampling.

Instrumen yang digunakan dalam penelitian ini merupakan instrumen yang dikembangkan dan dibuat sendiri oleh peneliti dengan tahapan, yaitu: 1) menyusun variabel penelitian, 2) menyusun kisi-kisi instrumen, 3) melakukan uji coba instrumen dengan melakukan pengujian validitas dan reabilitas instrumen.

Teknik analisis data yaitu dengan menggunakan gabungan antara statistik deskriptif dengan statistik inferensial. Statistik deskriptif berguna untuk mendeskripsikan demografi dari masingmasing variabel penelitian. Inferensial digunakan untuk menguji hipotesis penelitian dengan menggunakan analisa regresi yang di dahului dengan: 1) Uji normalitas data, 2) Uji Multikolinieritas, dan 3) Uji Linieritas.

\section{HASIL PENELITIAN DAN PEMBAHASAN}

Deskripsi data dari sisi demografi terhadap masing-masing variabel

a. Variabel Motivasi Kerja (Y) Dilihat dari Sisi Demografi

Variabel motivasi kerja dilihat dari sisi gender, secara statistik guru perempuan memiliki motivasi kerja yang lebih tinggi dari pada guru laki-laki hal ini ditandai dengan nilai rata-rata 4,28 berbanding 4,22. Profesi guru selalu identik dengan perempuan, hal ini bisa dilihat dari perbandingan jumlah guru yang ada pada suatu sekolah. Jumlah guru perempuan selalu lebih banyak dari pada guru laki-laki. Jiwa pendidik seorang guru perempuan lebih terpanggil dari pada guru laki-laki dalam mendidik anak-anak. Sementara itu, jika dilihat dari sisi usia dan masa kerja, guru yang berusia 51-60 dan 41-50 tahun memiliki motivasi yang lebih tinggi yaitu nilai rata-rata sebesar 4,29 dibandingkan dengan guru yang berusia 31-40 tahun sebesar 4,20 dan 21-30 tahun sebesar 4,13. Hal ini diakibatkan oleh guru yang berusia 41-60 tahun dan masa kerja yang lebih lama (21-30) tahun, lebih banyak mendapatkan peran dan tanggung jawab disekolah. Dengan demikian, pengalaman kerja seseorang maka akan membuat seseorang tersebut semakin terampil dalam mengerjakan tugasnya. Secara keseluruhan bahwa motivasi kerja guru di lingkungan Yayasan Pendidikan Cendana dilihat dari skor mean dan secara demografi, berada dalam tafsiran sangat tinggi.

\section{b. Variabel Beban Kerja (X1) Dilihat dari Sisi Demografi}

Variabel beban kerja dilihat dari sisi gender, secara umum guru perempuan memiliki beban kerja yang lebih tinggi dari pada guru laki-laki, hal ini ditandai dengan nilai rata-rata 4,01 berbanding 3,93 . Beban kerja guru berupa tugas rutin yang diberikan oleh pihak sekolah, guru perempuan lebih mampu dalam menjabarkan dan melaksanakannya dengan baik, termasuk dalam mengerjakan tugas-tugas tambahan. Meskipun tugas tambahan sangat menyita waktu guru dalam mengerjakan tugas pokok. Tugas tambahan berada pada tingkat yang tinggi, ditandai dengan nilai rata-rata sebesar 3,69 .

Sementara itu, jika dilihat dari sisi usia dan masa kerja, guru yang berusia 5160 tahun dan masa kerja 21-30 tahun memiliki beban kerja yang paling tinggi dengan nilai rata-rata (skor mean) sebesar 
4,09 dan 4,11. Usia dan masa kerja yang lama mengindikasikan bahwa kemampuan yang dimiliki seseorang dalam mengelola tugas dapat berjalan dengan baik. Pengalaman demi pengalaman mengajarkan seseorang dapat berbuat lebih baik. Hal ini senada dengan Robbins dalam (Bernhard Tewal, dkk, 2017) yang menyatakan bahwa masa kerja yang diekspresikan sebagai pengalaman kerja, tampaknya menjadi prediktor yang baik terhadap produktivitas karyawan. Secara keseluruhan bahwa beban kerja guru di lingkungan Yayasan Pendidikan Cendana dilihat dari skor mean demografi, berada dalam tafsiran tinggi.

\section{c. Variabel Kejenuhan Kerja Dilihat dari Sisi Demografi}

Variabel kenjenuhan kerja dilihat dari sisi gender, secara umum guru perempuan memiliki kejenuhan kerja yang lebih tinggi dari pada guru laki-laki, hal ini ditandai dengan nilai rata-rata 3,95 berbanding 3,89. Hal ini disebabkan karena secara kodratnya perempuan memiliki fisik yang lebih lemah dibandingkan laki-laki.

Sementara itu, jika dilihat dari sisi usia dan masa kerja, guru yang berusia 2140 tahun dan masa kerja 1-10 tahun memiliki tingkat jenuh yang paling tinggi dengan nilai rata-rata (skor mean) sebesar 4,04 dan 4,09. Meskipun kelompok umur 41-60 tahun serta masa kerja 21-30 tahun juga menderita kejenuhan kerja yang tinggi yaitu berada pada skor mean 3,92 dan 3,90. Hal ini menandakan tingkat kejenuhan kerja yang terjadi pada guru berada pada level yang tinggi. Hal ini sesuai dengan pendapat Greg Weiss dalam (Frank Chung, 2019) yang menyatakan bahwa generasi muda lebih mudah bosan dalam bekerja disertai dengan kinerja buruk, terlambat ke kantor dan sering dalam membuat kesalahan, serta memiliki keinginan yang kuat untuk berganti pekerjaan baru. Berdasarkan uraian tersebtu maka, secara keseluruhan bahwa kejenuhan kerja guru di lingkungan Yayasan Pendidikan Cendana dilihat dari skor mean demografi, berada dalam tafsiran tinggi.

\section{Pengujian Persyaratan Analisis}

\section{a. Pengujian Normalitas Variabel Penelitian}

Pada kolom Kolmogorov-Smirnov, diperoleh nilai signifikansi variabel beban kerja $\left(X_{1}\right)$ sebesar 0,200 , nilai signifikansi variabel kejenuhan kerja $\left(\mathrm{X}_{2}\right)$ sebesar 0,200 serta nilai signifikansi variabel motivasi kerja (Y) sebesar 0,200. Nilai signifikansi dari masing-masing variabel lebih besar dari 0,05. Dengan demikian dapat disimpulkan bahwa ketiga variabel penelitian berdistribusi normal.

\section{b. Pengujian \\ Multikolinieritas \\ Variabel Bebas \\ Pada kolom Variance Inflation} Factor (VIF) diperoleh bahwa besarnya nilai VIF pada variabel beban kerja $\left(\mathrm{X}_{1}\right)$ sebesar 1,024, dan variabel kejenuhan kerja $\left(\mathrm{X}_{2}\right)$ sebesar 1,024 . Besarnya nilai VIF dari masing-masing variabel menunjukkan lebih kecil dari 10. Hal ini menunjukkan tidak terjadi multikolinieritas diantara variabel bebasnya.

\section{Pengujian Hipotesis Penelitian}

\section{a. Pengujian Hipotesis I: Pengaruh Beban Kerja (X1) Terhadap Motivasi Kerja (Y)}

Hipotesis pertama yang diuji dalam penelitian ini adalah "terdapat pengaruh yang signifikan antara beban kerja $\left(\mathrm{X}_{1}\right)$ terhadap motivasi kerja (Y)". Untuk pengujian hipotesis menggunakan analisis regresi dan korelasi sederhana. Hasil uji pengaruh variabel beban kerja dengan motivasi kerja disajikan dalam tabel berikut ini. 
Tabel 1 Hasil Uji Pengaruh antara variabel Beban Kerja (X) terhadap Motivasi Kerja (Y)

\begin{tabular}{|c|l|c|c|c|}
\hline \multirow{2}{*}{ Model } & \multirow{2}{*}{ Variabel } & $\begin{array}{c}\text { Unstandardized } \\
\text { Coefficients }\end{array}$ & \multirow{2}{*}{$\mathrm{t}$} & \multirow{2}{*}{ Sig } \\
\cline { 3 - 3 } & B & & \\
\hline \multirow{2}{*}{1} & Konstanta & 54,768 & 4,878 & 0,000 \\
\cline { 2 - 5 } & Beban Kerja & 0,493 & 4,676 & 0,000 \\
\hline
\end{tabular}

Dari tabel 1 di atas diperoleh informasi bahwa persamaan regresi yang terbentuk adalah $\hat{Y}=54,768+0,493 X_{1}$. Berdasarkan persamaan regresi tersebut jika beban kerja guru sama dengan nol, maka nilai motivasi kerja guru yang dapat dipertahankan adalah sebesar 54,768. Koefisien regresi (b) sebesar 0,493 artinya, bahwa setiap ada penambahan satu satuan dari beban kerja, maka juga akan diikuti peningkatan motivasi kerja sebesar 0,493. Dari output tersebut besarnya nilai thitung $=4,676$ dengan probabilitas sig $=0,000$. Besarnya nilai $t_{\text {tabel }}$ dengan $\mathrm{n}=52$, variabel $\mathrm{k}=2, \mathrm{df}=\mathrm{n}-\mathrm{k}$, diperoleh $t_{\text {tabel }}=2,01$. Sehingga $t_{\text {hitung }}>t_{\text {tabel }}$ dan nilai sig $0,000<0,05$. Berdasarkan uraian tersebut maka dapat disimpulkan terdapat pengaruh yang signifikan antara beban kerja $\left(\mathrm{X}_{1}\right)$ terhadap motivasi kerja (Y).

Selanjutnya untuk mengetahui besarnya pengaruh atau koefisien determinasi antara variabel beban kerja $\left(\mathrm{X}_{1}\right)$ terhadap motivasi kerja $(\mathrm{Y})$ disajikan dalam tabel berikut ini.

Tabel 2 Pengaruh Variabel Beban Kerja (X1) terhadap Motivasi Kerja (Y)

\begin{tabular}{|c|c|c|c|c|c|}
\hline Model & Predictor & $\mathbb{R}$ & $\mathbf{R}^{2}$ & Persentase & Justifikasi \\
\hline 1 & Beban Kerja & 0,552 & 0,304 & $30,4 \%$ & Rendah \\
\hline
\end{tabular}

Pada tabel 2 diperoleh nilai R Square $\left(r^{2}\right)$ sebesar 0,304, dengan demikian pengaruh beban kerja terhadap motivasi kerja guru adalah sebesar 30,4\%. Sedangkan sisanya $69,6 \%$ ditentukan oleh variabel lain yang tidak dapat dijelaskan dalam penelitian ini. Dengan demikian, maka besarnya pengaruh variabel beban kerja $\left(\mathrm{X}_{1}\right)$ terhadap motivasi kerja $(\mathrm{Y})$ berada pada level rendah.

\section{b. Pengujian Hipotesis II: Pengaruh Kejenuhan Kerja $\left(\mathbf{X}_{2}\right)$ Terhadap Motivasi Kerja (Y)}

Hipotesis kedua yang diuji dalam penelitian ini adalah "terdapat pengaruh yang signifikan antara kejenuhan kerja $\left(\mathrm{X}_{2}\right)$ terhadap motivasi kerja (Y)". Hasil uji pengaruh variabel kejenuhan kerja dengan motivasi kerja disajikan dalam tabel berikut ini.

Tabel 3 Hasil Uji Pengaruh antara variabel Kejenuhan Kerja $\left(\mathbf{X}_{2}\right)$ terhadap Motivasi Kerja (Y)

\begin{tabular}{|c|l|c|c|c|}
\hline \multirow{2}{*}{ Model } & \multirow{2}{*}{ Variabel } & $\begin{array}{c}\text { Unstandardized } \\
\text { Coefficients }\end{array}$ & \multirow{2}{*}{$\mathrm{t}$} & \multirow{2}{*}{ Sig } \\
\cline { 3 - 3 } & Konstanta & 143,759 & 14,756 & 0,000 \\
\hline \multirow{2}{*}{1} & Kontann & $-0,393$ & $-3,777$ & 0,000 \\
\cline { 2 - 3 } & Kejenuhan Kerja & & \\
\hline
\end{tabular}

Dari tabel 3 di atas diperoleh informasi bahwa persamaan regresi yang terbentuk adalah $\hat{Y}=143,759-0,393 X_{2}$. Berdasarkan persamaan regresi tersebut jika kejenuhan kerja guru sama dengan nol, maka nilai motivasi kerja guru yang dapat dipertahankan adalah sebesar 143,759. Koefisien regresi (b) sebesar 0,393 artinya bahwa setiap ada penambahan satu satuan dari kejenuhan kerja, maka akan diikuti dengan penurunan motivasi kerja sebesar 0,393. Dari output tersebut besarnya nilai $t_{\text {hitung }}=$ 3,777 dengan probabilitas sig $=0,000$. Besarnya nilai $t_{\text {tabel }}$ dengan $n=52$, variabel $\mathrm{k}=2, \quad \mathrm{df}=\mathrm{n}-\mathrm{k}, \quad$ diperoleh $\quad \mathrm{t}_{\text {tabel }}=2,01$. Sehingga $t_{\text {hitung }}>t_{\text {tabel }}$ dan nilai sig $0,000<$ 
0,05. Berdasarkan uraian maka dapat disimpulkan terdapat pengaruh yang signifikan antara kejenuhan kerja $\left(\mathrm{X}_{2}\right)$ terhadap motivasi kerja (Y).

Selanjutnya untuk mengetahui besarnya pengaruh atau koefisien determinasi antara variabel kejenuhan kerja $\left(\mathrm{X}_{2}\right)$ terhadap motivasi kerja $(\mathrm{Y})$ disajikan dalam tabel berikut ini.

Tabel 4 Hasil Uji Pengaruh antara Variabel Kejenuhan Kerja ( $\left.\mathbf{X}_{2}\right)$ terhadap Motivasi Kerja (Y)

\begin{tabular}{|c|c|c|c|c|c|}
\hline Model & Predictor & $\mathbb{R}$ & $\mathbb{R}^{2}$ & Persentase & Justifikasi \\
\hline 1 & Kejenuhan Kerja & 0,471 & 0,222 & $22,2 \%$ & Rendah \\
\hline
\end{tabular}

Pada tabel 4 diperoleh nilai R Square $\left(r^{2}\right)$ sebesar 0,222, dengan demikian pengaruh kejenuhan kerja terhadap motivasi kerja guru adalah sebesar $22,2 \%$. Sedangkan sisanya 77,8\% ditentukan oleh variabel lain yang tidak dapat dijelaskan dalam penelitian ini. Dengan demikian, maka besarnya pengaruh variabel kejenuhan kerja $\left(\mathrm{X}_{2}\right)$ terhadap motivasi kerja $(\mathrm{Y})$ berada pada level rendah.

\section{c. Pengujian Hipotesis III: Pengaruh Beban Kerja (X1) dan Kejenuhan $\operatorname{Kerja}\left(\mathbf{X}_{2}\right)$ Terhadap Motivasi Kerja (Y)}

Hipotesis ketiga yang diuji dalam penelitian ini adalah "terdapat pengaruh yang signifikan antara beban kerja $\left(\mathrm{X}_{1}\right)$ dan kejenuhan kerja $\left(\mathrm{X}_{2}\right)$ terhadap motivasi kerja (Y)". Hasil uji pengaruh variabel beban kerja dan kejenuhan kerja dengan motivasi kerja disajikan dalam tabel berikut ini.

Tabel 5 Hasil Uji Pengaruh antara variabel Beban Kerja $\left(\mathrm{X}_{1}\right)$ dan Kejenuhan Kerja $\left(\mathbf{X}_{2}\right)$ terhadap Motivasi Kerja (Y)

\begin{tabular}{|c|c|c|c|c|c|}
\hline \multirow[t]{2}{*}{ Model } & \multirow[t]{2}{*}{ Variabel } & $\begin{array}{c}\text { Unstandardized } \\
\text { Coefficients }\end{array}$ & \multirow[t]{2}{*}{$\mathrm{F}$} & \multirow[t]{2}{*}{$t$} & \multirow[t]{2}{*}{ Sig } \\
\hline & & B & & & \\
\hline \multirow{3}{*}{1} & Konstanta & 91,314 & \multirow{3}{*}{20,606} & 6,499 & 0,000 \\
\hline & Beban Kerja & 0,439 & & 4,603 & 0,000 \\
\hline & Kejenuhan Keria & $-0,330$ & & $-3,710$ & 0,00 \\
\hline
\end{tabular}

Dari tabel 5 di atas diperoleh informasi bahwa persamaan regresi yang terbentuk

$\hat{Y}=91,314+0,439 X_{1}-0,330 X_{2}$.

Berdasarkan persamaan regresi tersebut jika beban kerja dan kejenuhan kerja guru sama dengan nol, maka nilai motivasi kerja guru yang dapat dipertahankan adalah sebesar 91,314. Koefisien regresi beban kerja $\left(b_{1}\right)$ sebesar 0,439 artinya, bahwa setiap ada kenaikan satu satuan dari beban kerja, maka akan diikuti dengan peningkatan motivasi kerja sebesar 0,439 dengan asumsi variabel kejenuhan kerja tetap. Koefisien regresi kejenuhan kerja $\left(b_{2}\right)$ sebesar $-0,330$ artinya, bahwa setiap ada kenaikan satu satuan dari kejenuhan kerja, maka akan diikuti dengan penurunan motivasi kerja sebesar 0,330 dengan asumsi variabel beban kerja tetap. Dari output tersebut besarnya $F_{\text {hitung }}$ sebesar 20,606 dengan nilai signifikan = 0,000 . Selanjutnya besarnya $F_{\text {tabel }}$ dengan $\mathrm{n}=52$, variabel $\mathrm{k}=3$, df $1=\mathrm{k}-1$, df $2=\mathrm{n}-\mathrm{k}$ diperoleh $F_{\text {tabel }}=3,19$. Sehingga $F_{\text {hitung }}>$ $\mathrm{F}_{\text {tabel }}$ dan nilai sig $0,000<0,05$. Dengan demikian maka dapat disimpulkan bahwa terdapat pengaruh yang siginifikan antara beban kerja $\left(\mathrm{X}_{1}\right)$ dan kejenuhan kerja $\left(\mathrm{X}_{2}\right)$ terhadap motivasi kerja (Y).

Selanjutnya untuk mengetahui besarnya pengaruh atau koefisien determinasi antara variabel beban kerja $\left(\mathrm{X}_{1}\right)$ dan kejenuhan kerja $\left(\mathrm{X}_{2}\right)$ terhadap motivasi kerja (Y) disajikan dalam tabel berikut ini.

\begin{tabular}{|c|c|c|c|c|c|}
\hline Model & Predictor & $\mathbf{R}$ & $\mathbf{R}^{2}$ & Persentase & Justifikasi \\
\hline 1 & $\begin{array}{c}\text { Kejenuhan_Kerja, } \\
\text { Beban_Kerja }\end{array}$ & 0,676 & 0,457 & $45,7 \%$ & Sedang \\
\hline
\end{tabular}


Tabel 6 Pengaruh Variabel Beban Kerja $\left(X_{1}\right)$ dan Kejenuhan Kerja $\left(X_{2}\right)$ terhadap Motivasi Kerja (Y)

\section{SIMPULAN}

Berdasarkan hasil penelitian yang telah dilaksanakan, maka dapat disimpulkan sebagai berikut: 1) Diperoleh pengaruh yang positif dan siginifikan antara variabel beban kerja terhadap motivasi kerja guru sebesar 30,4\% dengan tafsiran rendah. Dengan bertambahnya beban kerja maka motivasi kerja juga akan meningkat. Hal ini bermakna guru mampu menjabarkan dan memandang setiap beban kerja dengan baik, seperti memandang beban kerja dari sisi yang positif. 2) Variabel kejenuhan kerja memiliki pengaruh yang negatif dan signifikan terhadap motivasi kerja guru di Yayasan Pendidikan Cendana. Besarnya pengaruh antara beban kerja terhadap motivasi kerja guru sebesar 22,2\%. Pengaruh variabel kejenuhan kerja terhadap motivasi kerja tersebut berada pada tafsiran rendah. 3) Diperoleh pengaruh yang siginifikan secara bersamasama antara variabel beban kerja dan kejenuhan kerja terhadap motivasi kerja sebesar $45,7 \%$ dengan tafsiran sedang, karena masih terdapat $54,3 \%$ ditentukan oleh faktor lain yang tidak menjadi bagian dari penelitian ini.

\section{UCAPAN TERIMA KASIH}

Pada akhirnya, penulis menyadari bahwaartikel ini tidak akan selesai tanpa dukungan dari rekan-rekan majelis guru SMA Cendana Pekanbaru atas segala bantuan dan dukungan yang telah diberikan.

\section{DAFTAR PUSTAKA}

Dedi Santoso, Tetra Hidayanti, S. M., 2016. Pengaruh kejenuhan kerja dan kualitas kehidupan kerja terhadap kinerja penyuluh pertanian. Jurnal Feb Unmul, 1(1), 1-9.

Fitria, Hasnah Faizah, \& Azhar, 2017. Hubungan Antara Motivasi Kerja dan Kepuasan Kerja dengan Kinerja Guru Di SMK Negeri Se Kecamatan Rambah Kabupaten Rokan Hulu. Jurnal Manajemen Pendidikan, 5(1), 58-64.

Hamzah B. Uno, 2017. Teori Motivasi dan Pengukurannya, PT. Bumi Aksara, Jakarta.

Hari Mulyadi, \& Nina Marliana, 2010. Pengaruh Motivasi Dan Disiplin Kerja Karyawan Terhadap Kinerja Karyawan Pada Departemen Weaving PT. Adetex Cabang Banjaran Kab. Bandung. Strategic: Jurnal Pendidikan Manajemen Bisnis, 9(1), 40-75. https://doi.org/10.17509/strategic.v1 0i1.1077

Husmiati Yusuf, 2011. Pengaruh kondisi organisasi terhadap kejenuhan kerja pekerja sosial yang bekerja di panti sosial penyandang cacat di indonesia. Informasi, 16(03), 177-187.

Kementrian Pendidikan Nasional, 2009. Peraturan Menteri Pendidikan Nasional tentang Pemenuhan Beban Kerja Guru dan Pengawas Satuan Pendidikan (Permendiknas no. 39 Tahun 2009. http://disdik.bandungkab.go.id/site/r eadmore/21?render=product

Kurniadin, D., \& Machali, I., 2016. Manajemen Pendidikan (Konsep \& Prinsip Pengelolaan Pendidikan). ArRuzz Media.

Lia Amalia, 2017. Pengaruh Beban Kerja 
Dan Komitmen Terhadap Kinerja

Dan Kepuasan Kerja Perawat

Sebagai Variabel Intervening Pada

Rumah Sakit Tabrani RAB

Pekanbaru. Jurnal Online

Mahasiswa Fakultas Ekonomi

Universitas Riau, 4(9), 3415-3428.

https://doi.org/10.1017/CBO978110

7415324.004

M. Hasby, 2017. Pengaruh Konflik Kerja, Beban Kerja dan Komunikasi terhadap Stres Kerja Perawat Bagian Rawat Inap (pada RSUD. Petala Bumi Pekanbaru). Jurnal Online Mahasiswa Fakultas Ekonomi Universitas Riau, 4(1), 884-898.

M. Rizal Arfani, B. S. L., 2018. Pengaruh stres kerja dan beban kerja terhadap kinerja karyawan di PT. Sucofindo cabang Bandung effect of work stress and workload on employee performance in. 5(2), 2770-2785. https://libraryeproceeding.telkomuni versity.ac.id/index.php/management/ article/view/6981

Malayu Hasibuan, 2016. Organisasi dan Motivasi, PT. Bumi Aksara, Jakarta.

Maslach, C., \& Leiter, M. P., 2016. Burnout. Stress: Concepts, Cognition, Emotion, and Behavior: Handbook of Stress, June, 351-357.
https://doi.org/10.1016/B978-0-12800951-2.00044-3

Muchlisin Riadi, 2018. Pengertian, Dimensi dan Pengukuran Beban Kerja - KajianPustaka.com. https://www.kajianpustaka.com/201 8/01/pengertian-dimensi-danpengukuran-beban-kerja.html

Qureshi, S., 2013. The Relationship between Work Motivation, Burnout and Intention to Leave for the Top Level Managers of Garment Industry (A Case Study of Indian Garment Industry). International Journal of Human Resource Studies, 3(4), 128. https://doi.org/10.5296/ijhrs.v3i4.46 09

Riny Chandra, D. A., 2017. Pengaruh Beban Kerja dan Stres Kerja terhadap Kinerja Karyawan pada PT. Mega Auto Central Finance Cabang di Langsa. Jurnal Manajemen Dan Keuangan Unsam, 6(1), 670-678.

Suharti Ningsih, 2017. Pengaruh Kejenuhan Kerja, Beban Kerja, dan Konflik Kerja Terhadap Motivasi Kerja Perawat RSUD Dr. RM. Pratomo Bagan Siapiapi Kabupaten Rokan Hilir. JOM Fekon, 4(1), 495509. 